\title{
How the COVID-19 Pandemic is Challenging Consumption
}

\author{
Marine Cambefort \\ University of Strasbourg
}

Follow this and additional works at: https://digitalcommons.uri.edu/mgdr

Part of the Anthropology Commons, Economics Commons, Environmental Studies Commons, Food Studies Commons, Marketing Commons, Other Business Commons, Psychology Commons, Public Health Commons, and the Sociology Commons

\section{Recommended Citation}

Cambefort, Marine (2020) "How the COVID-19 Pandemic is Challenging Consumption," Markets, Globalization \& Development Review: Vol. 5: No. 1, Article 2.

DOI: 10.23860/MGDR-2020-05-01-02

Available at: https://digitalcommons.uri.edu/mgdr/vol5/iss1/2

This Article is brought to you for free and open access by DigitalCommons@URI. It has been accepted for inclusion in Markets, Globalization \& Development Review by an authorized editor of DigitalCommons@URI. For more information, please contact digitalcommons-group@uri.edu. 


\section{How the COVID-19 Pandemic is Challenging Consumption}

\section{Cover Page Footnote}

The author thanks Remy Guichardaz and Fabien Pecot for their comments.

\section{Markets, Globalization \& Development Review}
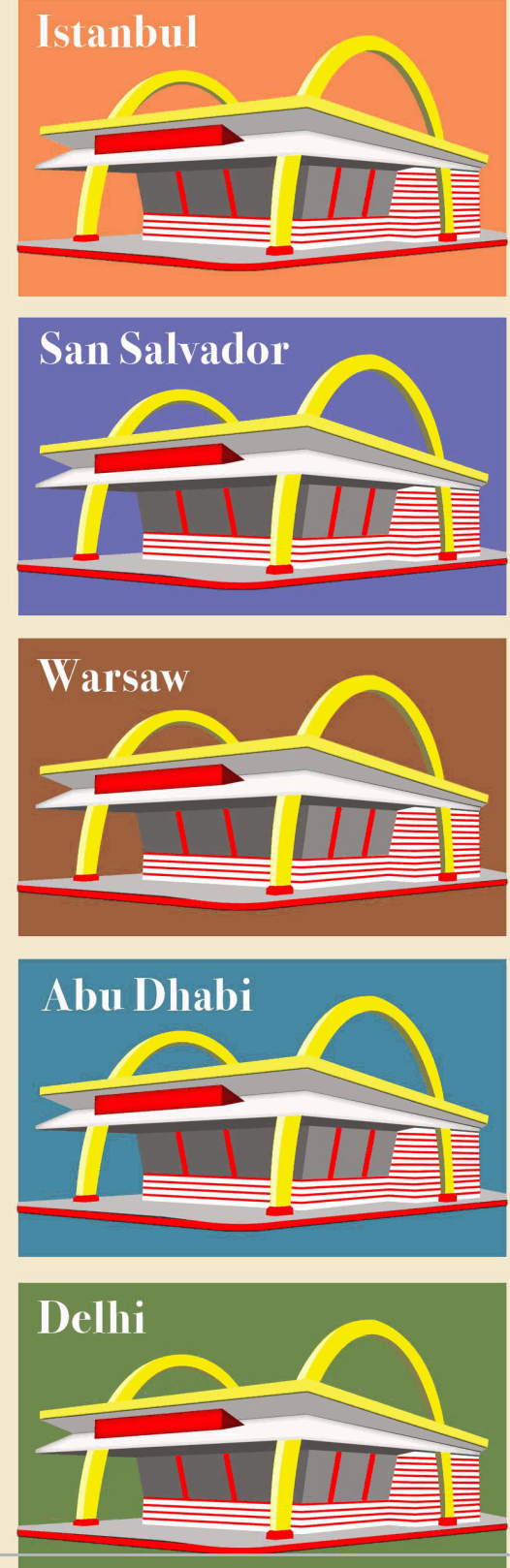
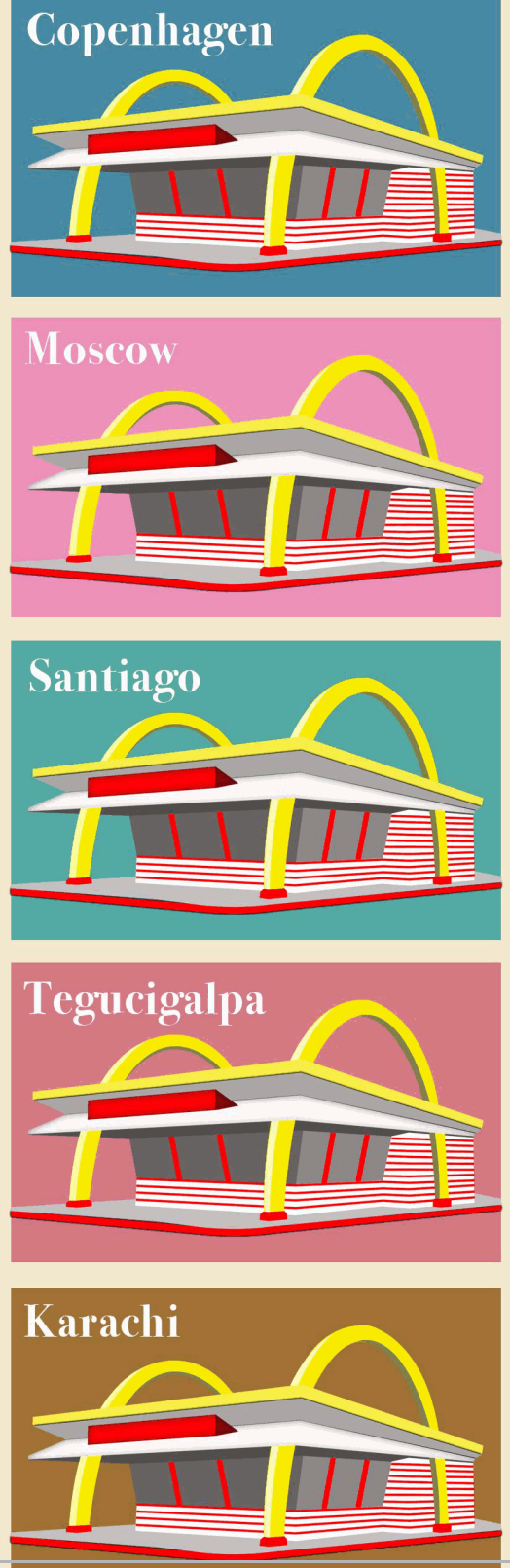
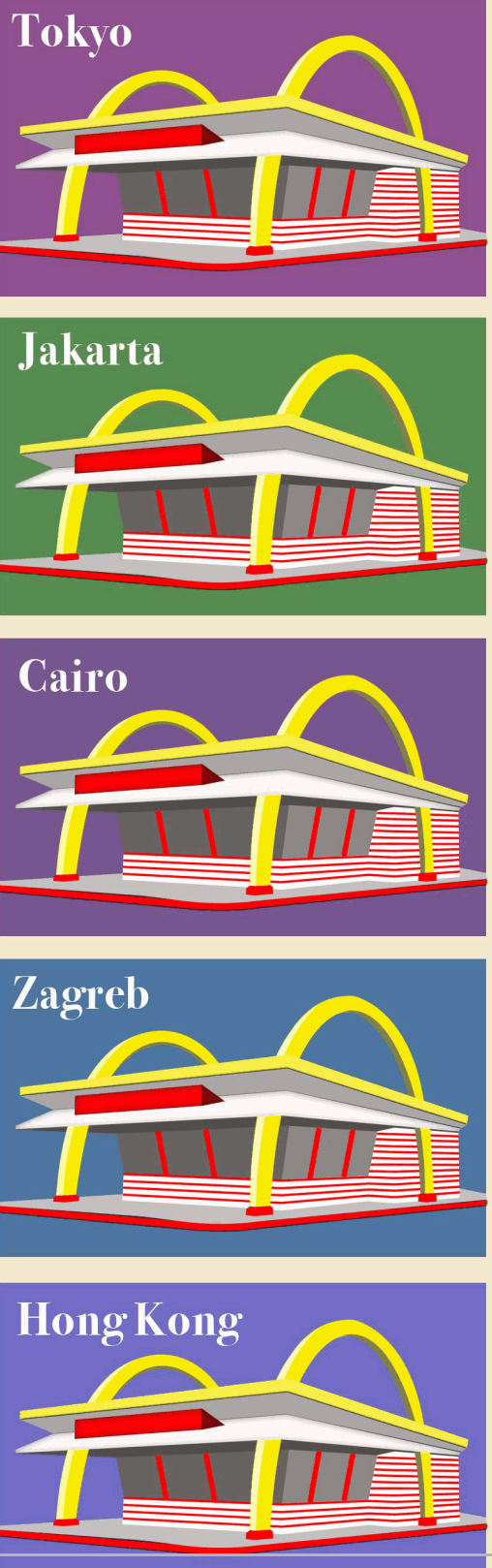

This article is available in Markets, Globalization \& Development Review: https://digitalcommons.uri.edu/mgdr/vol5/ 


\section{How the COVID-19 Pandemic is Challenging Consumption}

\section{Introduction}

COVID-19 disrupted consumption habits all around the world. To keep in touch with friends and family during lockdowns, and with social distancing requirements, there was an increased use of digital technologies such as videotelephony and online chat platforms. These conditions also boosted telehealth, telecommuting, e-commerce and online education (Kirk and Rifkin 2020). The use of social media such as Facebook, WhatsApp, and Zoom also increased (Sheth 2020). The virus outbreak triggered hoarding (Kirk and Rifkin 2020; Long and Khoi 2020; Sheth, 2020), defined as the accumulation of large private stocks of goods because of a perceived risk of shortage (Sterman and Doğan 2015). A fear of shortages led many individuals to stockpile daily necessities such as toilet paper, bread, water and cleaning products. At the same time, consumers turned to do-ityourself and home-based activities such as cooking or gardening (Kirk and Rifkin 2020). Finally, the pandemic may have triggered a sustainable consumption transition (Cohen 2020). Recent management and marketing research publications - including the ones cited - have begun to identify consumption trends resulting from the pandemic.

While the aforementioned studies focus on how the virus outbreak affects consumer choices, less attention has been paid to the possible anti-consumption and curtailed/reduced consumption outcomes of the pandemic. This paper aims to address the following question: how does the COVID-19 outbreak challenge consumption?

Researchers in management, and particularly in marketing, have already shown some interest in anti-consumption. Special issues have been dedicated to this concept in academic journals over the last decade such as, Journal of Business Research in 2009; Consumption Markets \& Culture in 2010; European Journal of Marketing in 2011; Psychology and Marketing in 2020. As anti-consumption literally means against consumption, the study of this complex phenomenon focuses on the reasons against consumption (Chatzidakis and Lee 2013). This concept is related to (but different from) green activism, boycotts, avoidance and consumer resistance (Chatzidakis and Lee 2013). According to Makri et al. (2020), anti-consumption is intentional and meaningful. An unintentional or nonvoluntary reduction of consumption (for instance due to the 
unavailability of some products or brands) cannot therefore be considered as anti-consumption.

Three non-exclusive phenomena characterize anti-consumption (Lee et al. 2011), namely rejection, restriction and reclamation. Rejection is based on functional, ethical or symbolic reasons, and causes consumers to exclude particular goods from consumption. Restriction refers to the limitation of consumption when rejection is not possible (in cases such as an electricity or water supply). Finally, reclamation is the expression of ideological consumer opposition to consumption.

lyer and Muncy (2009) highlight two underlying dimensions of anticonsumption: purpose and object. "Purpose" indicates the motivations behind anti-consumption. People may be driven by societal issues (such as environmental protection or company misconduct) or by personal issues (such as simple living or negative experiences with a service provider). "Object" is defined as the target of antagonistic sentiment. The target can be general, for example an opposition to the market embodied by consumerist ideology or globalization, or involve a specific brand or a company, such as Starbucks (Izberk-Bilgin 2008) or Coca-Cola (Varman and Belk 2009). The target can also be a consumption practice, like the marketization of play in the video game sector (Almaguer 2018).

We will now investigate the three ways in which the current health crisis may challenge consumption: a decrease in consumption, an increase in anti-globalization sentiment, and consumer reactions to evidence of misconduct by brands and companies during the crisis.

\section{COVID-19 as A Catalyst for Downsizing Consumption}

"COVID-19 is simultaneously a public health emergency and a real-time experiment in downsizing the consumer economy" (Cohen 2020: 1). Social distancing and lockdown measures forced people to change their consumption patterns. In addition, many shops had to close temporarily. The pandemic has inexorably led to a general decrease in consumption.

"We don't need savings for our economy right now, we need investment". This declaration from the French Minister of Economy refers to the 3.8 billion euros that the French population saved in March 2020 by not investing in consumption. Studies all around the world illustrate the same downsizing trend.

In Japan, total spending decreased, across the board, by $14 \%$ between the second half of January and first half of March (Watanabe 2020). The COVID-19 epidemic has a negative impact on almost all sectors of the Japanese economy; the travel sector suffered the biggest spending crash $(-57 \%$ of credit card purchases), followed by 
accommodations $(-38 \%)$, transport $(-29 \%)$, and entertainment $(-26 \%)$. Meanwhile, the turnover of shopping centres decreased by $70 \%$ in the United States (Yelp 2020). Household spending declined by $40 \%$ to $50 \%$ in the United Kingdom (Hacıoğlu, Känzig and Surico, 2020), with the strongest impact felt by the retail (clothes, shoes, toys, and books), restaurant, transport and travel sectors. In France, $45 \%$ of people planned to reduce their shopping expenses by $28 \%$ after the lockdown (OpinionWay for Fastmag 2020). This intention to reduce consumption is driven by several factors, including budget constraints (59\%) or the fear of becoming ill (35\%).

Studies tend to confirm a general downsizing in consumption. Although this trend seems to be a "natural consequence" of the pandemic, some consumers have expressed a desire to lower their consumption over the long term. According to the results of the aforementioned OpinionWay poll, $42 \%$ of respondents who planned to cut down their shopping expenses had realized that many of their purchases are unnecessary. This deliberate decision to reduce consumption is a manifestation of anticonsumption sentiment about the current market and consumerist ideology.

The literature on anti-consumption explains this phenomenon. According to lyer and Muncy (2009), people can reduce their consumption for personal or societal reasons. Both motivations can lead consumers to adopt voluntarily simplified lifestyles (Shaw and Newholm 2002). Voluntary simplicity refers to the intentional simplification of consumption patterns. Voluntary simplifiers limit their expenditures, but also cultivate nonmaterialistic sources of satisfaction and meaning (Makri et al. 2020). Their discourses "highlight ecological uncertainty as a claim against consumer culture" (Cherrier 2009: 3). They denounce the accumulation of unnecessary material objects, and even warn against an "addiction" to consumption. They seek to avoid the marketplace by adopting alternative consumption behaviours such as sharing practices, making goods last longer, or buying second-hand products (Shaw and Newholm 2002). The virus outbreak and its consequences provided an opportunity to test a simpler lifestyle through consumption downsizing.

The lockdown led some people to realize that over-consumption does not make them happy, whilst others became aware of its negative impact on environment and the importance they accord to material possessions. A shift from short-term materialism to a more socially benevolent ethic should therefore be expected (Goffman 2020). 


\section{Anti-Globalization Sentiment}

The flow of people, trade and capital has slowed down since the outbreak of COVID-19. The current health crisis challenges globalization. Globalization is often perceived as "a negative, imperialistic force, killing local identities, forcing uniformity of culture and experience, and destroying independent self-determination" (FIrat 2016: 1). Recent studies reveal that the pandemic has catalyzed an increasing consumer preference for local supplies over global distributors and products (Yelp Coronavirus Impact Report 2020; Process Alimentaire 2020). A survey by OpinionWay for Max Haavelar reveals that 45\% of French consumers switched to local products during lockdown (Process Alimentaire 2020). COVID-19 also led these consumers to make more responsible purchases $(69 \%)$, and they intend to maintain this consumption habit after the crisis $(80 \%)$.

Some research in the field of marketing has addressed consumer anti-globalization thoughts. Consumers may reject global brands such as Coca-Cola and McDonalds due to anti-globalization sentiments. These brands are rejected because of their perceived hegemony and cultural imperialism (Lee, Motion and Conroy 2009; Izberk-Bilgin 2008; Sandıkçı and Ekici 2009; Varman and Belk 2009). Some consumers also have a patriotic connection to local brands: they buy locally to resist globalization and favor the economy of their own country (Lee, Motion and Conroy 2009). Furthermore, anti-consumption could be a consequence of tension between the national ethos and the global market when it is driven by nationalism (Cambefort and Pecot 2019).

The boycott of products made in China is another possible consequence of COVID-19. The fact that the pandemic began in China means that this country is strongly associated with the current health crisis, possibly leading to consumer animosity. Animosity is defined as anger felt toward a country due to past or present political, military, economic or diplomatic events (Klein, Ettenson and Morris 1998). This feeling may lead consumers to boycott a brand through animosity towards its country of origin (Klein, Ettenson and Morris 1998; Sandıkçı and Ekici 2009; Sun et al. 2020).

To conclude, COVID-19 may reinforce anti-globalization sentiment, leading consumers to abandon global brands in favor of local products. Hegemonic and Chinese brands are expected to be the most affected by this trend. It is not clear at this stage, however, whether such sentiments would persist in the longer run. 


\section{Misconduct by Brands and Companies}

According to the COVID-19 special edition of the Edelman Trust Barometer (2020), 78\% of respondents expected companies to protect their employees and the local community during the coronavirus crisis. In addition, most of them (79\%) also expected businesses to adapt (for instance, cancelling non-essential events). They massively (73\%) support an adaptation of Human Resources policies, including the provision of paid sick leave or instructing vulnerable employees to remain at home. These results indicate that consumers have been attentive to possible misconduct by companies during the pandemic and suggest that their future purchasing decisions should be impacted by the actions of brands.

As mentioned in the introduction, the object of anti-consumption can be a brand or a company. In this case, consumers - labelled as "market activists" by lyer and Muncy (2009) - develop a negative relationship with a specific entity because it causes a societal problem (for instance, negative social behavior). During the health crisis, companies took decisions that could be perceived negatively by consumers. Examples include Adidas and H\&M, who decided to stop paying their renting costs in Germany to deal with the strong sales decrease, or the two famous online retailers in France (La Redoute and Amazon) who were ordered to close down their warehouses during the lockdown because they did not ensure the safety and security of their staff.

The main motivation for anti-brand actions is the immoral behaviour of companies and brands (Zarantonello et al. 2016). Individuals oppose brands when they believe that company management policies have a negative impact on society (Lee, Motion and Conroy 2009), and decry brands that damage the environment or disregard human rights (Hegner, Fetscherin and van Delzen 2017). These negative relations lead to antagonistic behaviors, including switching (Romani et al. 2012), avoidance (Lee, Motion and Conroy, 2009; Hegner, Fetscherin and van Delzen 2017), complaint (Hegner, Fetscherin and van Delzen 2017; Johnson, Matear and Thomson, 2011), non-instrumental boycott (Friedman, 1999), activism (Cambefort and Roux, 2019) or even illegal actions (Johnson, Matear and Thomson 2011). Through these acts, consumers express their concern about the negative impact of a brand on society as a whole. As mentioned above, Amazon had to close its warehouses temporarily in France because it did not meet safety and security requirements for its employees. This ongoing conflict began during lockdown: In June, protesting activists accused the retailing giant Amazon of "re-poisoning the world". To sum up, pandemic-related 
wrongdoings by companies and brands are likely to be the target of anticonsumption.

\section{Collateral Damage of COVID-19: The Case of Corona Beer}

\section{Brand}

The recent experience of the Corona beer brand is a good example of how a focal brand can be the target of anti-consumption. This Mexican beer brand was impacted by the coronavirus pandemic when consumers associated the brand with the disease, resulting in a sales decrease. For instance, the number of French adults who prefer this brand decreased by 4.6 percentage points between January and February 2020 (Yougov 2020). Google Trends shows that web users associated the brand with the virus outbreak, with "beer virus" appearing as one of the most searched requests on search engines.

This conflation led to online parody, which can be used as a playful form of consumer resistance (Mikkonen and Badge 2013). A special offer in a Brussels shop informed customer that they could "Buy 2 Coronas, get a free Mort Subite" ("Mort Subite" is the name of another beer brand, and means "Sudden Death"). This special offer was appreciated by customers in the store, and the picture was spread widely on social networks.

The temporarily negative impact of the pandemic on Corona beer should therefore be considered as collateral damage. The brand had not committed any acts of social or environmental misconduct. The parody used by consumers here is not a form of aggressive anti-consumption; this kind of parodic content can even create an internet "buzz" that has a favorable impact on the brand. Corona's parent company stock has not declined in response to the pandemic (Yougov 2020), indicating that the behaviour of stakeholders was not impacted by brand parody.

\section{Concluding Comments}

The exceptional and rare situation of the COVID-19 crisis had led people to question their buying decisions and change their consumption patterns. This paper provides evidence that sheds light on the understudied impact of the pandemic on anti-consumption. Voluntary simplifiers reduced their overall expenses. Some consumers decided to buy locally rather than consume global products and brands. Market activists scrutinized companies to identify any social misconduct.

Voluntary simplicity, anti-globalization sentiment and boycotts are not new phenomena. The current health crisis should be considered as a catalyst that gives an impetus to existing anti-consumption actions. Further investigations are required to examine this trend in detail and understand 
why consumers choose to reduce their levels of consumption. More specifically, any societal or individual motivations triggered by the coronavirus pandemic should be investigated. Another major avenue of academic research concerns the consequences for brands that have been targeted because of their wrongdoing. Attention should also be paid to the short and long-term outcomes of the virus outbreak on brand image, consumer-brand relationship, and brand equity.

Anti-consumption sentiment leads to alternative consumption practices (Chatzidakis and Lee 2013). Voluntary simplifiers may decide to maintain their consumption rather than reduce it, and purchase mainly green brands, fair-traded goods, or local products (Shaw and Newholm 2002). Market activists may boycott one company and buycott another that is more respectful of staff safety and security (Friedman 1996). Producers play a role in this process. For instance, organic farmers encourage the construction of an alternative approach of food production and consumption, and this strengthens the movement for conventional food anti-consumption (Dalmoro de Matos and de Barcellos 2020).

After the crisis, most consumers will return to their previous habits. Nonetheless, individuals will have had the time to question their own consumption and to discover alternatives (Sheth 2020). We can therefore expect a catalyst effect of COVID-19 on anti-consumption over the long term. 


\section{References}

Almaguer, Jacob C. (2018), "Gamer Resistance to Marketization of Play," Markets, Globalization \& Development Review, 3 (3), Article 5.

Cambefort, Marine and Fabien Pecot (2019), "Theorizing Rightist AntiConsumption," Marketing Theory, 20 (3), 385-407. https://doi.org/10.1177/1470593119895792

Cambefort, Marine and Elyette Roux (2019), "A Typology of the Perceived Risks in the Context of Consumer Brand Resistance," Journal of Product \& Brand Management, 28 (5), 575-85. https://doi.org/10.1108/JPBM-03-2018-1792

Chatzidakis, Andreas and Lee Michael (2013), "Anti-Consumption as the Study of Reasons Against," Journal of Macromarketing, 33 (3), 190203. https://doi.org/10.1177/0276146712462892

Cherrier, Hélène (2009), "Anti-Consumption Discourses and ConsumerResistant Identities," Journal of Business Research, 62 (2), 181-90. https://doi.org/10.1016/j.jbusres.2008.01.025

Cohen, Maurie J. (2020), "Does the COVID-19 Outbreak Mark the Onset of a Sustainable Consumption Transition?," Sustainability: Science, Practice and Policy, (accessed on June 18, 2020), [available at: https://doi.org/10.1080/15487733.2020.1740472]

Dalmoro, Marlon, Celso de Matos and Marcia D. de Barcellos (2020), "Anticonsumption Beyond Consumers: The Role of Small Organic Producers in Environmentally Oriented Anticonsumption,"

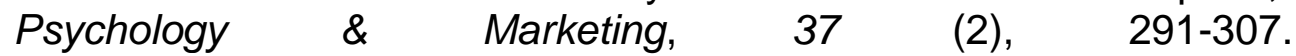
https://doi.org/10.1002/mar.21300

Edelman Trust Barometer (2020), "Special Report on COVID-19 Demonstrate Essential Role of the Private Sector," (accessed on June 22, 2020), [available at: https://www.edelman.com/research/edelman-trust-covid-19demonstrates-essential-role-of-private-sector]

Fırat, A. Fuat (2016), "The Dynamics of the Local and the Global: Implications for Marketing and Development," Markets, Globalization \& Development Review 1 (1), Article 4.

Friedman, Monroe (1999), Consumer Boycotts: Effecting Change through the Marketplace and the Media. Psychology Press.

---- (1996), "A Positive Approach to Organized Consumer Action: The "Buycott" as an Alternative to the Boycott," Journal of Consumer Policy, 19, 439-51. https://doi.org/10.1007/BF00411502 
Goffman, Ethan (2020), "In the Wake of COVID-19, is Glocalization our Sustainability Future?," Sustainability: Science, Practice and Policy, 16 (1), 48-52. https://doi.org/10.1080/15487733.2020.1765678

Hacıoğlu, Sinem, Känzig Diego and Paolo Surico, (2020), "Consumption in the Time of COVID-19: Evidence from UK Transaction Data," Discussion Paper DP14733, Centre for Economic Policy Research. (accessed on Sep. 16, 2020), [available at:

https://cepr.org/active/publications/discussion_papers/dp.php?dpno= 14733]

Hegner, Sabrina, Marc Fetscherin, and Marianne van Delzen (2017), "Determinants and Outcomes of Brand Hate," Journal of Product and Brand Management, 26 (1),13-25. https://doi.org/10.1108/JPBM-012016-1070

lyer, Rajesh and James A. Muncy (2009), "Purpose and Object of AntiConsumption," Journal of Business Research, 62 (2), 160-68. https://doi.org/10.1016/j.jbusres.2008.01.023

Izberk-Bilgin, Elif (2008), When Starbucks Meets Turkish Coffee: Cultural Imperialism and Islamism As 'Other' Discourses of Consumer Resistance in NA - Advances in Consumer Research, 35, ed. Angela Y. Lee and Dilip Soman, Duluth, MN: Association for Consumer Research, 808-09.

Johnson, Allison R., Maggie Matear and Matthew Thomson (2011), "A Coal in the Heart: Self-relevance as a Post-exit Predictor of Consumer Anti-brand Actions," Journal of Consumer Research, 3 (1), 108-25. https://doi.org/10.1086/657924

Kirk, Colleen P. and Laura Rifkin (2020), "I'll Trade You Diamonds for Toilet Paper: Consumer Reacting, Coping and Adapting Behaviors in the COVID-19 Pandemic," Journal of Business Research, 124-31. https://doi.org/10.1016/j.jbusres.2020.05.028

Klein, Jill Gabrielle, Richard Ettenson, and Marlene D. Morris (1998), "The Animosity Model of Foreign Product Purchase: An Empirical Test in the People's Republic of China," Journal of Marketing, 62 (1), 89-100. https://doi.org/10.1177/002224299806200108

Lee, Michael, Motion J and Conroy D (2009), "Anti-Consumption and Brand Avoidance," Journal of Business Research 62 (2), 169-80. https://doi.org/10.1016/i.jbusres.2008.01.024

Lee, Michael, Dominique Roux, Hélène Cherrier and Bernard Cova (2011), "Anti-Consumption and Consumer Resistance: Concepts, Concerns, Conflicts and Convergence," European Journal of Marketing, 45, 11-12. https://doi.org/10.1108/ejm.2011.00745kaa.001 
Long, Nguyen Ngoc and Bui Huy Khoi (2020), "An Empirical Study about the Intention to Hoard Food during COVID-19 Pandemic," Journal of Mathematics, Science and Technology Education, 16 (7). https://doi.org/10.29333/ejmste/8207

Makri, Katerina, Bodo B. Schlegelmilch, Robert Mai and Katharina Dinhof (2020), "What We Know about Anticonsumption: An Attempt to Nail Jelly to the Wall," Psychology \& Marketing, 37 (2), 177-215. https://doi.org/10.1002/mar.21319

Mikkonen, Ilona and Domen Bajde (2013), "Happy Festivus! Parody as Playful Consumer Resistance," Consumption Markets \& Culture, 16 (4), 311-37. https://doi.org/10.1080/10253866.2012.662832

OpinionWay for Fastmag (2020), "Sondage sur la Consommation des Français en «Textile et Habillement» Après le Confinement," (accessed on June 12, 2020), [available at: https://www.fastmag.fr/sondage-fastmag-realise-par-opinionway/]

Process Alimentaire (2020), "Covid-19: Vers Une Consommation Plus Responsible?," (accessed on June 17, 2020), [available at: https://www.processalimentaire.com/vie-des-iaa/covid-19-vers-uneconsommation-plus-responsable?sso=1592661090]

Romani, Simona, Silvia Grappi and Daniele Dalli (2012), "Emotions that Drive Consumers away from Brands: Measuring Negative Emotions toward Brands and their Behavioral Effects," International Journal of Research in Marketing, 29 (1), 55-67. https://doi.org/10.1016/.ijiresmar.2011.07.001

Sandıkçı, Özlem and Ahmet Ekici (2009), "Politically Motivated Brand Rejection," Journal of Business Research, 62 (2), 208-17. https://doi.org/10.1016/i.jbusres.2008.01.028

Shaw, Deirdre and Terry Newholm (2002), "Voluntary Simplicity and the Ethics of Consumption," Psychology \& Marketing, 19 (2), 167-85.

Sheth, Jagdish (2020), "Impact of Covid-19 on Consumer Behavior: Will the Old Habits Return or Die?," Journal of Business Research, 17, 280-83. https://doi.org/10.1016/j.jbusres.2020.05.059]

Sterman, John D., and Gökhan Doğan (2015), "I'm not Hoarding, I'm just Stocking Up Before the Hoarders Get Here: Behavioral Causes of Phantom Ordering in Supply Chains," Journal of Operations Management, 39, 6-22. https://doi.org/10.1016/j.jom.2015.07.002

Sun, Qi, Fang Wu, Shanjun Li and Rajdeep Grewal (2020), "Consumer Boycotts, Country of Origin, and Product Competition: Evidence from China's Automobile Market," (accessed on Sep. 16, 2020), [available at: http://dx.doi.org/10.2139/ssrn.3142667 ] 
Varman, Rohit and Russel W. Belk (2009), "Nationalism and Ideology in an Anticonsumption Movement," Journal of Consumer Research, 36 (4), 686-700. https://doi.org/10.1086/600486

Watanabe Tsutomu (2020), The Responses of Consumption and Prices in Japan to the COVID-19 Crisis and the Tohoku Earthquake. Working paper, Center on Japanese Economy and Business, Columbia Business School, (accessed on Sep. 1, 2020), [available at: www.gsb.columbia.edu/cjeb/research]

Yelp (2020), "Coronavirus Economic Impact Report," (accessed on June 17, 2020), [available at: https://www.yelpeconomicaverage.com/yelpcoronavirus-economic-impact-report]

Yougov (2020), Fort Impact de L'amalgame Entre le Coronavirus et la Bière Corona, (accessed on June 12, 2020), [available at: https://fr.yougov.com/news/2020/02/07/amalgame-entre-lecoronavirus-et-biere-corona/]

Zarantonello, Lia, Simona Romani, Silvia Grappi and Richard P. Bagozzi (2016), "Brand Hate," Journal of Product \& Brand Management, 25 (1), 11-25. https://doi.org/10.1108/JPBM-01-2015-0799 